\title{
THE COUNCIL OF EUROPE AND ITS CONSECRATION REGULATIONS AND PROTECTION OF HUMAN RIGHTS \\ T. Tănăsescu
}

\section{Tudor Tănăsescu}

Law Faculty, „Bioterra” University from Bucharest, Romania

* Corespondenţă: Tudor Tănăsescu, str. Pescăruşului nr.3, Bl. B-24, Sc.3, Et. 6, Ap.145, Sector

2, Bucureşti, România.

E-mail: tanasescutudor@yahoo.com

\begin{abstract}
The Council of Europe is the main international organization with vocation intergovernmental regional/European which has the fundamental objective consecration and protection of human rights. The Organization shall constitute the institutional framework in which had been initiated and developed, under the aspect its rules and mechanisms, the best international system in human rights domain, European system consecration and protection of human rights.

Main conventional legal instruments in the promotion and protection of human rights domain at the European level, adopted within the framework of the Council of Europe, on the basis of which have been created and the institutions and mechanisms specific to this field are: the Convention for the protection of human rights and fundamental freedoms, European Social Charter and the European Convention on indefeasibility war crimes and crimes against humanity, European Convention for the prevention of torture and inhuman or degrading treatment or, framework Convention for the protection of ethnic minorities national, and so on.
\end{abstract}

\section{Keywords: The Council of Europe, human rights, consecration, protection, European Conventional tools.}

\section{Introduction}

European system for the protection of human rights is currently the most effective and efficient system of protection and guarantee, through specific mechanisms, human rights and its fundamental ${ }^{1}$ freedoms. This was done, in the main, within the institutional framework of the Council of Europe, in close liaison with the United Nations, afterwards being developed and at the European Union level and the Organization for Security and Cooperation in Europe.

European States, members of the Council of Europe, support and promote through their national laws the consecrated values and protected by European legal instruments in the human rights domain.

The Council of Europe is currently main intergovernmental international organization at European level which has the consecration main missions and defense of human rights. Setting up of the National Council of Europe the surrounding with the attainment of united Europe under institutional aspect, through the creation of European organizations covering political and economic integration of the states in the region.

The organization has been set up in London on 5 May 1949, by the representatives of ten European $^{2}$ countries that have signed the Council of Europe ${ }^{3}$. Creating organization has been determined by the need for expressed by the Member States to preserve "moral values and

\footnotetext{
${ }^{1}$ Scăunaş Stelian, International law of human rights. University Course, All. Beck Publishing House, Bucharest, 2003, p.54; Tănăsescu Tudor, International law of human rights. University Course, Sitech Publishing House, Craiova, 2013, p. 59.

2 Belgium, Denmark, France, Ireland, Italy, Luxembourg, The Netherlands, Great Britain, Norway and Sweden.

3 The text of the Statutes in the Official Gazette, Part I, no. 238 of 4 October 1993.
} 
spiritual which constitute both common heritages of the peoples as well as their true source of individual freedom, political freedom and the rule of law".

The aim of the Council of Europe is to achieve a greater unity among its members for safeguarding and promoting ideas and principles which are their common heritage and facilitating their economic and social ${ }^{4}$ progress.

The members of the Council of Europe are European states which recognize the Status organization and who fulfill the following conditions:

- supports principles of the rule of law;

- supports principle whereby each person under his jurisdiction should enjoy fundamental human rights and freedoms;

- undertake to cooperate sincerely and effectively, to achieve the aim of the organization.

They are members of the Council of Europe 47 European $^{5}$ States.

The main conventional rules adopted by the Council of Europe consecration and protection of human rights are the Convention for the protection of human rights and fundamental freedoms, its done at Rome on 4 November 1950 and European Social Charter, which was adopted on 18 October 1961 and revised in the year 1996. Also, on the basis of these treated, subsequently, have been adopted and other legal instruments which affects concerns of the protection of human rights domain.

Consideration of conventional tools consecration and protection of human rights adopted and established under the aegis of the Council of Europe

A. European Convention for the protection of human rights and fundamental freedoms and its Protocols additions.

European Convention for the protection of human rights and fundamental freedoms (also called the European Convention of Human Rights) is the main regulations adopted in conventional protection of human rights domain at the European level, within the framework of the Council of Europe. On the basis of the document has been created, in addition to the regime of rights and legal institutions and mechanisms necessary its implementation. The Convention was adopted in Rome on 4 November 1950 and entered into force on 3 September $1953^{6}$.

This document has been designed as a means of collective guarantee, international human rights and not as a procedure to replace national systems for the protection of human rights ${ }^{7}$.

The Convention lays down that the aim of the Council of Europe is to achieve a greater unity between its members and that one of the means to achieve this purpose is the protection and development of human rights and fundamental freedoms ${ }^{8}$. The document has been adopted by asserting by participating States of their commitment to these fundamental freedoms which forms the basis of justice and peace in the world and whose compliance is based on a political regime truly democratic, on the one hand, and, on the other hand, on a common approaches and a respect of human rights which they recognize?

In its original form, Title I of the Convention, consecrate and guarantees the rights and freedoms:

- the right to life (Article 2);

\footnotetext{
4 Ibidem, art.1 letter b).

5 Romania has been received in the year 1993 and has been subject to monitoring up to the year 1997.

6 The text in Vida Ioan, Human rights in international regulations, Lumina Lex Publishing House, Bucharest 1999, p. 287-310.

7 Beşteliu Raluca Miga and colab., International protection of human rights. Courses Notes, Edition IV reviewed, Universul Juridic Publishing House, Bucharest, 2008, p. 64; Tănăsescu Tudor, International law of human rights. University Course, Sitech Publishing House, Craiova, 2013, op. cit., p.60; Niciu I. Marţian, Public international law, Servosat Publishing House, Arad, 2004, p. 222.

8 Vida Ion, op.cit., preamble.

9 Ibidem, preamble.
} 
- the right not to be subjected to torture or other treatments or inhuman punishments or degrading treatment (Article 3);

- the right to not be held in slavery or in terms of obedience and not be forced to perform forced labor (Article 4);

- the right to freedom and safety (Article 5);

- the right to a fair trial carried out within a reasonable time, in an independent court established by law (Article 6);

- the right to not be convicted of an act or omission which, at the time it was committed, did not constitute a criminal offense and shall not apply to a more severe punishment than that which was applicable at the time (Article 7);

- the right to respect of privacy, family, of residence and mail (Article 8);

- the right to freedom of thought, conscience and religion (Article 9);

- the right to freedom of expression (Article 10);

- the right to freedom of association and peaceful assembly (Article 11);

- the right to marry and to found a family (Article 12);

- the right to appeal (Article 13).

The Convention also contains a clause non-discriminatory basis (Article 14), in accordance with which states parties are obliged to provide exercise of the rights and freedoms recognized by it, without distinction based, in particular, on sex, color, language, religion, political or any other opinion, national or social origin, membership of a national minority, property, birth or any other situation.

The document provides for a derogation clause, according to which, in the event of war or other public danger, which threaten life nation, any state member may take measures derogating from the provisions of the Convention, but they are not in conflict with the obligations arising from international law (Article 15). The Convention also allows any restriction placed on political activity of aliens with regard to freedom of peaceful assembly and freedom of association.

But there are some fundamental rights and freedoms of the Convention does not accept no derogation. They are:

a) the right of every person to life, except in the case of death arising as a result of unacceptable acts of war;

b) the right not to be subjected to torture or to punishment or inhuman treatment or degrading;

c) the right not to be held in slavery or in terms of obedience;

d) the right not to be convicted of an act or omission which, at the time it was committed, did not constitute a criminal offense and shall not apply to a more severe punishment than that applicable to the offense committed.

- Title II of the Convention has been established the mechanism for the implementation of its provisions which, initially, consisted in creating European Commission of Human Rights and the European Court of Human Rights. This mechanism, consecrated by the Convention, has been reconfigured by adopting Protocol No. 11 of 11 May $1994^{10}$, within the meaning of that, of the two bodies there has been created a unique court, respectively European Court for Human Rights. This means the institution international the most performance in the protect human rights domain.

Titles III and IV of the European Convention of Human Rights governing problematic organization and functioning of the two bodies which compose the mechanism for the implementation of its provisions, i.e. the Commission for Human Rights and European Court of Human Rights. Title V of the document includes final provisions relating to certain obligations of the States Parties, the interpretation of its provisions, settlement of disputes, its entry into force, and so on.

\footnotetext{
${ }^{10}$ It has entered into force in 1998.
} 
The Convention for the protection of human rights and fundamental freedoms, was amended and supplemented by 14 additional $^{11}$ protocols, regarding the initial text update recording with the developments at the level of countries or in interstate relations in Europe.

Additional Protocol No. 1 of the Convention was adopted in Paris on 20 March 1952 and in addition to the catalog of rights and fundamental freedoms provided for by the Convention, the following:

- the right to respect property;

- the right to education; and

- the right to free elections.

Additional Protocol No. 2, shall be adopted in the year 1963, in Strasbourg, supplement the Convention by allocating European Court for Human Rights jurisdiction to give advisory opinions on legal issues concerning the interpretation of the Convention and the related Protocols.

Additional Protocol No. 3, adopted in the year 1970, in Rome, changed the text of that Article 30 of the Convention in 1950, regarding the mode for the adoption of decisions of the European Commission of Human Rights. At present the Protocol is inapplicable whereas it has carried out its dissolution Commission concerned.

Additional Protocol No. 4, has been adopted in the year 1963 in Strasbourg and governing certain rights and freedoms, other than those which are proclaimed by the Convention and the Protocol. It is a case of:

a) the right of a person not to be deprived of freedom for the sole reason that he is not in a position to perform a contractual obligation;

b) the right to freedom of movement, a free choice residence and to leave any country, including its own;

c) the individual right not to be expelled from the territory of the State of which he is a citizen;

d) the individual right to enter the territory of the State of which he is a citizen;

$\boldsymbol{e})$ the prohibition on collective expulsions by foreigners.

Additional Protocol No. 5, adopted in the year 1971, in Rome, changed the Article 40 of the Convention in 1950, governing the procedure for the election of the members of European Court of Human Rights.

Additional Protocol No. 6, adopted in 1983, in Strasbourg, regulate abolish death penalty, with the exception of acts committed in time of war or imminent danger of war.

Additional Protocol No. 7, has been adopted in the year 1984, in Strasbourg. This document complements the Convention by recognition of new rights, such as:

a) the right to procedural guarantees for foreign citizens, before being expelled from the country where they are resident;

b) the right to appeal in criminal cases;

c) the right not to be pursued or punished for an offense for which he or she has already been paid or sentenced by a final judgment;

d) the right to compensation in the event of miscarriage;

e) the husbands equality before the law and their responsibilities with civil character, among themselves, in their relations with their children, in respect of the marriage.

Additional Protocol No. 8, has been adopted in the year 1990 at Strasbourg, makes some changes to the procedural rules, established by the Convention, in particular with regard to the creation of rooms within the Commission to improve its activity. At present such amendments are no longer applicable since the Commission has been dissolved.

\footnotetext{
${ }^{11}$ Romania has ratified the Convention by Law No. 30 of 18 May 1994, published in the Official Gazette No. 135 of 31 May 1994. By the same law was ratified its Additional Protocols 1-10. Protocol No. 11 was ratified in August 1995, the Protocol No. 13 has been ratified on January 92003 and the Protocol No.14 by the Law No. 39 of 22 March 2005. All the Member States of the Council of Europe (46) are parties to the Convention.
} 
Additional Protocol No. 9, has been adopted in Rome on 6 November 1990, and has been carried out amend of certain provisions relating to the procedures of the Commission and Court, as well as individuals' access to the European Court of Human Rights (in particular their quality recognition) and non-governmental organizations and individuals.

Additional Protocol No. 10, it has also been adopted in Strasbourg on 25 March 1992, and by amending the procedure by the Committee of Ministers as regards its competence in the line monitoring respect for human rights by the States Party to the Convention. Its provisions have been repealed after two years as a result of the adoption of Protocol No. 11.

Additional Protocol No. 11, as adopted in Strasbourg on 11 May 1994, carried out reform control mechanism established by the European Convention of Human Rights, by replacing Commission and the Court with a new court, unique and permanent in human rights protection domain - European Court of Human Rights.

Additional Protocol No. 12, was adopted in Rome on 4 November 2000, proclaimed principle of non-discrimination no matter what criteria or reasons would be able to do that.

Additional Protocol No. 13, it has also been adopted in Vilnius on 3 May 2002 and devote abolish death penalty in any circumstance. It shall complete the provisions of the additional Protocol No. 6.

Additional Protocol No. 14 adopted in Strasbourg on 13 May 2004 stipulates amend of the control system set up by the Convention for the protection of human rights and fundamental freedoms adopted in Rome on 4 November 1950, in order to maintain and strengthen its longterm effectiveness of the control system aimed at implementation of the provisions of this Convention.

\section{B. European Social Charter}

European Social Charter was adopted in Torino, within the framework of the Council of Europe, on 18 October 1961 and entered into force on 26 February $1965^{12}$. The Charter is designed to supplement the Convention provisions for the protection of human rights and fundamental freedoms (which includes mainly civil and political rights), with a catalog of economic, civil and cultural rights. In the contents are set out seven Charter social rights, supereminent, which forms the core of the document, namely: the right to work, the right to organise in trade unions, the right to collective bargaining, the right to social security, the right to social and medical assistance, family right to social protection, legal and economic and the right of workers and their families to protection and assistance.

The Particularity Charter adopted in Torino consists in the possibility of partial acceptance of its provisions in the context of signing it. Therefore, in order to become a party to the Charter, a member state must accept at least 10 items (out of the 19) or 45 subparagraphs (of the 72 paragraphs of the articles of the Charter numbering) provided that supported among the provisions to be contained in 5 articles of the 7 which form the core of hard rights stipulated by the Charter.

The Charter was subsequently supplemented by 3 protocols: Additional Protocol of 5 May 1988, which entered into force on 4 September 1992, to develop category economic and social ${ }^{13}$ rights, the Protocol for the amendment to the Charter on 21 October 1991 aimed at changes in the mechanism of supervising the application of the Charter and additional Protocol to the European Social Charter 9 November 1995, entered into force on 1 July 1998, which set up a system of collective complaints.

12 On 13 March 2007, a number of 27 states were parties to European Social Charter.

13 The Protocol stipulates and ensures effective exercise of the following rights: the right to opportunities and equal treatment in matters of employment and occupation; employees' rights to information and consultation; workers' right to participate in the establishment and improvement of the conditions of employment and the right of aged persons to social protection. 
C. In the year 1996 was adopted European Social Charter Revised, which entered into force on 1 July $1992^{14}$. rights:

European Social Charter Revised acknowledges the following social and economic

1. the right to work (Article 1);

2. right to fair conditions of employment (Article 2);

3. the right to safety and hygiene of work (Article 3);

4. the right to equitable remuneration (Article 4);

5. the syndicate right (Article 5);

6. the right to collective bargaining (Article 6);

7. the right of children and young persons to protection (Article 7);

8. the right to the protection workers maternity (Article 8);

9. the right to vocational guidance (Article 9);

10. the right to vocational training (Article 10);

11. the right to protection of health (Article 11);

12. the right to social security (Article 12);

13. the right to social and medical assistance (Article 13);

14. the right to benefit from social services (Article 14);

15. the right of the disabled to autonomy, social integration and participation in the life of the Community (Article 15);

16. the family right to social protection, legal and economic (Article 16);

17. the right of children and young people in social protection, legal and economic (Article $17)$;

18. the right to pursue a gainful occupation in the territory of the other party (Article 18);

19. the right of migrant workers and their families to protection and assistance (Article 19);

20. the right to equality of opportunity and treatment in respect of employment and occupation, without discrimination on the basis of sex (Article 20);

21. the right to information and consultation (Article 21);

22. the right to take part in the determination and improvement of the conditions of employment and the working environment (Article 22);

23. the right of aged persons to social protection (Article 23);

24. the right to protection in the event of dismissal (Article 24);

25. the right of workers to protect their own claims in the event of the insolvency of their employer (Article 25);

26. the right to dignity at work (Article 26);

27. the right work with family responsibilities of equality of opportunities and treatment (Article 27);

28. the right of workers' representatives to protection for the undertaking and to their facilities (Article 28);

29. the right to information and consultation procedures in collective redundancies (Article 29);

30. the right to protection against poverty and social exclusion (Article 30);

31. the right to a home (Article 31).

European Social Charter Revised added to the list of rights which form the core of resistance social rights, the children's rights and the young to protection (Article 6) and the right of equality of opportunity and treatment in respect of employment and occupation without discrimination on the basis of sex (Article 20).

By the law of ratification of European Social Charter Revised, Romania has stated that: "In accordance with the provisions of Article A paragraph 1 of Part III of the European Social Charter Revised, Romania supports Part I of this Charter, a statement which determine objectives

14 On 1 March 2008 were parties to the Charter 24 Member States of the Council of Europe. Romania has ratified the Charter on 3 May 1999 by Law No. 74, published in the Official Gazette No.193/ 4 May 1999. 
to be carried out will follow by all means useful and shall be regarded as lawful by the provisions of Article 1, Article 4-9, Article 11,12, 16,17, 20,21, 24,25, 28 and 29, as well as in addition to the provisions of Article 2, paragraphs 1, 2, 4-7, Article 3, paragraphs 1-3, Article 13 paragraphs 1-3, Article 15 paragraphs 1 and 2, Article 18 paragraphs 3 and 4 and Article 19 paragraphs 7 and 8 and Article 27 paragraph $2^{15}$ ".

European Social Charter Revised replaced by the States which become part of it, European Social Charter and its Protocols.

Additional Protocol in the year 1995, which shall provide for a system of collective complaints continued to be applied to European Charter Reviewed as additional protocol.

- For the purpose of compliance by the States Party to European Social Charter provisions, respectively, the European Social Charter Revised was set up a mechanism for monitoring, which involves two procedures of control: control procedure carried out on the basis of reports and collective complaints procedure.

Control procedure carried out on the basis of reports

By the protocol for the amendment to the Charter of 1991 is hereby established a committee of independent experts (which replaced, at the request of Ministers Committee, the Committee of Experts) consisting of 9 members, chosen the Parliamentary Assembly of the Council of Europe for a period of 6 years from a list of experts nominated by the States Parties. Members shall exercise the mandate in their individual capacities with complete independence. The test procedure involves an obligation on Member parties to submit half-yearly report on application of the provisions of the Charter (Part II) which they have accepted. In addition, Member Parties to an agreement may submit to Secretary General of the Council of Europe at certain intervals and at the request of Ministers Committee reports on charter provisions which they have not accepted no when ratifying and no later. The state reports are examined by the Committee of Independent Experts. After the examination, reports together with the observations made by the Committee of Independent Experts, are sent to a government Committee created based on the Protocol amendment to the Charter, a body that replaces Subcommittee Government Social Committee. The Committee governmental, Composed of one representative of each of the States parties (the European Social Charter Revised), on the basis of the reports, observations of the Committee of Independent Experts, as well as the comments of observers invited, prepares resolutions and recommendations of the Committee of Ministers of the Council of Europe in respect of situations recorded in practice of the member, including related breaches of obligations entered into by them.

At present the Committee of Independent Experts shall be called the European Committee of Social Rights ${ }^{16}$.

Collective complaints procedure

It was introduced by Additional Protocol to European Social Charter of 1995, which entered into force in 1998.

According to Article 1 of the Protocol of 1995, have the right to make collective complaints concerning breach of certain provisions of European Social Charter and the Protocol of 1995, the European Social Charter Revised, these features:

a. international organizations of employers and employed persons invited to meetings of the Committee governmental;

b. other international non-governmental organizations with consultative status in addition to the Council of Europe;

c. national organizations representing employers and employees.

Procedure has two stages, the admissibility of the exam complaint, reflected by a decision on the admissibility, and step examination as to substance.

15 In accordance with Article 2 of Law No. 74/199 for the ratification European Social Charter Revised.

16 See Miga-Beşteliu Raluca and collab., op. cit., p.273 
The complaint must be made in writing and shall contain information necessary for identification of the possible incorrect application of the Charter. The complaint submitted by Secretary General of the Council of Europe will be sent the Committee of Independent Experts.

The state party against whom it is directed the complaint will be informed of this.

If the complaint is admissible, the Committee shall inform the States party to the Charter and ask the Member State concerned and applicant organization's comments on the fund.

On the fund complaint pronounced the Committee of Independent Experts by means of a report in which he/she shall submit its conclusions; the report is sent to the Committee of Ministers and shall be served on the applicant and the member parties, without leaving their possibility to publish it.

On the basis of the report the Committee, the Committee of Ministers has adopted $\underline{\mathrm{a}}$ resolution or, a recommendation in the event of incorrect application of the Charter. This document of the Committee of Ministers together with the report of the Committee of Independent Experts can be made available to the public by Parliamentary Assembly.

\section{Other treaties on human rights adopted by the Council of Europe}

Other category of treaties made in the area of human rights at the European level are:

a) European Convention on the legal status of migrant worker adopted on 24 November $1977^{17}$. This covers legal situation of migrant workers who are nationals of the Member States of the Council of Europe, in order to ensure, as far as possible, a treatment no less favorable than that enjoyed by those workers who are nationals of that State, connected with the living and working conditions;

b) European Convention for the prevention of being tortured and punished or inhuman treatment and degrading, done at Strasbourg on 26 November $1987^{18}$.

It has been drawn up with the aim of developing opportunities of persons considered victims of torture and inhuman or degrading treatment to benefit from assistance and out of a desire to enhance the protection of private persons freedom in this respect by the creation of a mechanism of preventive extra-judicial nature, based on visits;

c) European Charter of regional and minority languages. It was adopted on 5 November 1992 aiming at protecting and promoting regional and minority languages, procedure to order strictly cultural. The purpose of this Regulation is to ensure, as far as possible, using regional and minority languages in education, media, legal and administrative and economic, social and cultural fields;

d) The framework Convention for protection of national ${ }^{19}$ minorities. It was adopted on 1 February 1995;

The Convention lays down the obligations for the protection of national minorities and the rights of the persons belonging to them within the framework of the rule-of-law state, with due regard to the rules, The territorial integrity and national sovereignty;

e) The Convention on children's rights opened for signature ${ }^{20}$ in 1996 and entered into force on 1 July 2000.

\section{Conclusions}

The Council of Europe shall constitute the institutional framework in which it has been initiated and developed, under the aspect its rules and mechanisms, the most efficient international system in the human rights, the European system of consecration and protection of

17 It entered into force on 01.05.1983. Romania has not signed.

18 It entered into force on 1 February 1989. Romania has ratified the Convention by Law No. 80 of 30 September 1994, published in the Official Gazette no. 285/1994.

19 Romania has ratified the Convention-frame by Law No. 33 of 29 April 1995, published in the Official Gazette, Part I No. 82 of 4 May 1995; See Tanasescu Tudor, Minorities. Legislative and institutional marks, Sitech Publishing House, Craiova, 2006, p. 52-59.

20 Romania has ratified the Convention on 11 May 1995. 
human rights.

The conventional legal instruments of the European system for the promotion and guarantee of human rights adopted under the aegis Council of Europe, belong to the category of those with regional vocation and are developed in close connection with those of the United Nations.

The main Conventional legal regulations in the promotion and protection of human rights adopted within the framework of the Council of Europe on the basis of which they have been created institutions and mechanisms specific to this area have been: the Convention for the protection of human rights and fundamental freedoms, European Social Charter and the European Convention on indefeasibility war crimes and crimes against humanity and the European Convention for the prevention of torture and punishments and inhuman treatment or degrading, framework Convention for the protection of ethnic minorities national, and so on.

The protection and guarantee of human rights legal instruments established by conventional initiated and adopted by the Council of Europe shall be carried out through the mechanisms established by that organization on its regulations, by: the European Court on Human Rights (judicial mechanism) designed by the European Convention of human rights, and monitoring conventional mechanisms nonjurisdictionale, as well as periodic reporting system and that of collective complaints used by the European Committee of social rights, created on the basis European Social Charter or preventive supervision on the basis of surveys carried out by the European Committee for the prevention of torture and other punishment or inhuman or degrading treatment replaced by the European Convention for the prevention of torture.

Also, we notice some extra-conventional mechanisms, such as: the European Commission against Racism and Intolerance or Commissioner for Human Rights of the Council of Europe.

\section{Bibliography:}

- Tănăsescu Tudor, International law of human rights. University Course, Sitech Publishing House, Craiova, 2013;

- Tănăsescu Tudor, Public international law. University Course, Second edition revised and added, Sitech Publishing House, Craiova 2013;

- Beşteliu Raluca Miga and colab., International protection of human rights. Courses Notes, Universul juridic Publishing House, Bucharest, 2008;

- Selejan-Guţan Bianca, European Protection of Human Rights. Master, Ed. C.H. Beck Publishing House, Bucharest, 2008;

- Tanasescu Tudor, Minorities. Legislative and institutional marks, Sitech Publishing House, Craiova, 2006;

- Niciu I. Marţian, Public international law, Servosat Publishing House, Arad, 2004;

- Scăunaş Stelian, International law of human rights. University Course, All. Beck Publishing House, Bucharest, 2003;

- Vida Ioan, Human rights in international regulations, Lumina Lex Publishing House, Bucharest 1999;

- Marcu Viorel, International mechanisms to guarantee the human rights, Sigma Plus, Deva, 1998;

- Năstase Adrian, Human rights, religion at the end of the century, I.R.D.O., Bucharest, 1992 